\title{
Body surface area: a new anthropometric measurement for obstructive sleep apnea syndrome
}

\author{
Sibel DORUK ${ }^{1}$ \\ Handan iNÖNÜ \\ KÖSEOĞLU ${ }^{2}$ \\ Emel CEYLAN ${ }^{3}$
}

1 Ata Sağlık Hastanesi, Göğüs Hastalıkları Kliniği, İzmir, Türkiye

${ }^{1}$ Clinic of Chest Diseases, Ata Saglik Hospital, Izmir, Turkey

2 Tokat Gaziosmanpaşa Üniversitesi Tıp Fakültesi, Göğüs Hastalıkları Anabilim Dalı, Tokat, Türkiye

${ }^{2}$ Department of Chest Diseases, Faculty of Medicine, Gaziosmanpasa University, Tokat, Turkey

${ }^{3}$ Adnan Menderes Üniversitesi Tıp Fakültesi, Göğüs Hastalıkları Anabilim Dalı, Aydın, Türkiye

${ }^{3}$ Department of Chest Diseases, Faculty of Medicine, Adnan Menderes University, Aydın, Turkey

\section{SUMMARY}

Body surface area: a new anthropometric measurement for obstructive sleep apnea syndrome

Introduction: We aimed to explore the possibility of using body surface area (BSA) as a new anthropometric measurement in evaluation of OSAS.

Materials and Methods: Obesity was defined as having a $B M I \geq 30 \mathrm{~kg} / \mathrm{m}^{2}$. BSA were calculated using the Mosteller and Boyd formulas. Totaly 426 (306 male) cases were included in this study.

Results: The mean BMI was $33.0 \mathrm{~kg} / \mathrm{m}^{2}$. The mean BSA was $2.06 \mathrm{~m}^{2}$ and $2.11 \mathrm{~m}^{2}$ respectively. BMI, AHI, oxygen desaturation, ODI and oxygen saturation were found different between the groups. Both BMI and BSA correlated positively with AHI, oxygen desaturation and ODI and negatively with oxygen saturation. There was no difference between BMI and BSA in mild cases in both gender. However, in moderate and severe cases, BMI and BSA were higher in males. We dedected that BSA and BMI display similar sensitivity and specificity values for the prediction of severe OSAS.

Conclusion: To the best of our knowledge, this is the first study to examine the potential association between BSA and the severity of OSAS. As a result, we determined that BSA correlated with polisomnographic parameters as BMI. In severe OSAS BSA can be used as a predictor parameter like BMI.

Key words: Obstructive sleep apnea syndrome; obesity; body sur-

\section{Yazıșma Adresi (Address for Correspondence)}

\section{Dr. Sibel DORUK}

Ata Sağlık Hastanesi, iZMiR - TÜRKIYE

e-mail: sibeldoruk@yahoo.com 


\section{ÖZET}

Vücut yüzey alanı: obstrüktif uyku apne sendromu için yeni bir antropometrik ölçüm

Giriş: Obstrüktif uyku apne sendromu (OSAS) hastalarının değerlendirilmesinde vücut yüzey alanı (VYA)'nın yeni bir antropometrik ölçüm olarak kullanılıp kullanılamayacağını araştırmayı amaçladık.

Materyal ve Metod: Vücut kitle indeksinin (VKi) $\geq 30 \mathrm{~kg} / \mathrm{m}^{2}$ olması obezite olarak kabul edildi. BSA Mosteller ve Boyd formülleri kullanılarak hesaplandı. Bu çalışmaya toplam 426 (306 erkek) olgu dahil edildi.

Bulgular: Ortalama VKi $33.0 \mathrm{~kg} / \mathrm{m}^{2}$,VYA sırasıyla $2.06 \mathrm{~m}^{2}$ ve $2.11 \mathrm{~m}^{2}$ idi. VKi, AHi, oksijen desatürasyonu, oksijen desatürasyon indeksi (ODi) ve oksijen satürasyonu gruplar arasında farklı bulundu. Hem VKi hem de VYA AHI, oksijen desatürasyonu ve ODI ile pozitif ve oksijen satürasyonuyla negatif korelasyon gösterdi. Her iki cinsiyette de hafif olgularda VKi ve VYA açısından farklıık yoktu. Ancak orta ve ciddi olgularda erkeklerde VKi ve VYA daha yüksekti. VYA ve VKi'nin şiddetli OSAS'ın öngörülmesinde benzer duyarlılı ve özgüllügü olduğunu belirledik.

Sonuç: Bildiğimiz kadarıyla, bu çalışma BSA ile OSAS'ın ciddiyeti arasındaki potansiyel ilişkiyi inceleyen ilk çalışmadır. Sonuç olarak, VYA'nın VKi'sinde olduğu gibi polisomnografik parametrelerle korele olduğunu belirledik. A ̆̆ır OSAS olgularında VYA VKi gibi belirleyici bir parametre olarak kullanılabilir.

Anahtar kelimeler: Obstrüktif uyku apne sendromu; obezite; vücut yüzey alanı

\section{INTRODUCTION}

Obstructive sleep apnea syndrome (OSAS) is a condition characterized by recurrent partial or complete upper respiratory tract (URT) obstruction resulting in hypoxia/reoxygenation and arousals from sleep $(1,2)$. Approximately $3-7 \%$ of adult males and $2-5 \%$ of adult females in western countries and Asia suffer from symptomatic OSAS. Although the pathogenesis of OSAS has not been fully revealed, the basic anatomical characteristics of airway obstruction are well known (3). Factors known to diminish the width or facilitate the obstruction of URT predispose patients to OSAS. The most obvious risk factors are male gender and obesity. Moreover, smoking, alcohol consumption and physical inactivity appear to increase the tendency to this condition. Polysomnography (PSG) is required for establishment of a correct diagnosis as well as planning of treatment in patients with OSAS $(1,2,4)$.

The frequency of obesity, which is an obvious risk factor for OSAS, has increased in recent years (5). OSAS has been reported in $50-77 \%$ of obese patients in clinical practice (6). Various anthropometric measurements such as body mass index (BMI) [Weight $(\mathrm{kg}) /$ Height $\left.(\mathrm{m})^{2}\right]$, waist-to-hip ratio, and neck circumference (NC) are used to evaluate OSAS, which is a condition requering a proper physical examination (height, weight, body mass index, and cardiovascular evaluation), including exploration of the upper airway (7). Patients with OSAS exhibit significantly higher values of BMI, waist-to-hip ratio and neck circumference compared to control patients $(8,9)$. The frequency of severe OSAS is particularly high in patients with a BMI greater than $30 \mathrm{~kg} / \mathrm{m}^{2}$. Increased values of $\mathrm{BMI}$ and $\mathrm{NC}$ result in an increased apnea hypopnea index $(\mathrm{AHI})$, directly impacting on the severity of OSAS (10).

In recent years, increased frequency of obesity has brought about several questions related to the appropriate dose of various drugs administered to these patients. Weight and body surface area (BSA) are two factors employed to guide appropriate dosing in administration of various drugs (11). BSA plays a key role in several medical fields, including cancer chemotherapy, burn treatment and toxicology. It is an anthropometric measurement used especially in determination of appropriate chemotherapy dosing $(12,13)$. It is believed to be a better indicator of metabolic mass than body weight alone (14). It can be calculated using the formulas developed by Mosteller, Boyd and DuBois $(15,16)$. Mosteller (17). Formulas by Monsteller [Height $(\mathrm{cm}) \times$ Weight $(\mathrm{kg}) / 3600)^{1 / 2}$ ] and Boyd [Weight $(\mathrm{kg}) 0.4838 \times$ Height $(\mathrm{cm}) 0.3 \times$ 0.017827] are the most commonly used ones for BSA calculations (18). The correlation between the two formulas is rather high with only insignificant differences between the results obtained (19). For example, in a patient with a height of $160 \mathrm{~cm}$ and a weight of $80 \mathrm{~kg}$ Mosteller and Boyd formulas respectively give the following results for BSA: $1.89 \mathrm{~m}^{2}$ and $1.94 \mathrm{~m}^{2}$.

The purpose of the present study is to evaluate the association BSA (as calculated based on the Mosteller 
and Boyd formulas) might potentially have with several polisomograhpic parameters such as $\mathrm{AHI}$, oxygen desaturation level, sleep efficiency, oxygen desaturation index (ODI), mean oxygen saturation level and minimum oxygen saturation level in patients with OSAS and to explore the possibility of using BSA as a new anthropometric measurement in evaluation of OSAS.

\section{MATERIALS and METHODS}

This was a retrospective study. Participants of the study were selected from among patients who had undergone a sleep study due to the clinical suspicion of OSAS at the sleep study center of Gaziosmanpasa University Hospital between October 2012 and July 2016. Polysomnographic evaluation was performed in all patients. Patients were grouped into the following three categories based on their AHI calculated using the American Academy of Sleep Medicine (AASM) task force criteria: mild OSAS (AHI: 5-15), moderate OSAS (AHI: 15-30), and severe OSAS (AHI > 30) (20). Several polysomnographic parameters $(\mathrm{AHI}$, oxygen desaturation level, sleep efficiency, ODI, mean oxygen saturation level, minimum oxygen saturation level) as well as age, gender, height and body weight of the patients were recorded. Age below 18 years and presence of central sleep apnea syndrome, upper airway resistant syndrome, narcolepsy or movement disorders constituted the exclusion criteria. The study was in compliance with the principles outlined in the Declaration of Helsinki and approved by the Local Ethics Committee.

Overnight PSG was performed in all patients using a 55-channel polysomnograph (Alice ${ }^{\circledR}$ Sleepware, Philips Respironics, USA) and included the following variables: electrooculograms (two channels), electroencephalograms (four channels), electromyograms of the submental muscles (one channel), and anterior tibialis muscle of both legs (two channels); electrocardiograms, airflow measurements (with oro-nasal thermistor and nasal cannula pressure transducer), body position sensor which discerns changes in body position during sleep, and a snore sensor for detection of snoring vibrations. Respiratory efforts that the chest and the abdominal muscles exerted (two channels) were recorded using piezo-electric belts, and arterial oxyhaemoglobin saturation $\left(\mathrm{SaO}_{2}\right.$ : one channel) was observed using pulse oximetry with a finger probe. The recordings were scored according to the standard criteria of AASM. Apnea was defined as a $\geq 90 \%$ decrease in the airflow amplitude that persisted for at least 10 seconds relative to the baseline values. Hypopnea was defined as a $\geq 50 \%$ decrease in the airflow amplitude relative to the baseline values associated with $\mathrm{a} \geq 3 \%$ oxygen desaturation or arousals from sleep, all lasting for at least 10 seconds (20). AHI represented the number of apneic plus hypopneic episodes per hour of sleep. Patients with an $\mathrm{AHI} \geq 5$ were diagnosed as having OSAS. Lastly, ODI represented the hourly average number of desaturation episodes defined as an at least $4 \%$ decrease in oxygen saturation from the average oxygen saturation in the preceding 120 seconds that lasted for at least 10 seconds.

Obesity was defined as having a BMI $\geq 30 \mathrm{~kg} / \mathrm{m}^{2}$ according to the criteria of the World Health Organization (21). BMI and BSA were calculated using the formulas developed by Mosteller and Boyd. In this respect, two different automatic BSA calculator systems were employed.

Data were analyzed using SPSS for Windows 15.00 statistical package program. A $p$ value smaller than 0.05 was considered statistically significant. Mean values of $\mathrm{BMI}, \mathrm{BSA}, \mathrm{AHI}$, oxygen desaturation, sleep efficiency, ODI, mean saturation and minimum oxygen saturation were calculated. The correlation BSA and BMI might potentially have with the said polysomnographic parameters was analyzed using the Pearson correlation analysis. Whether the patients grouped based on their AHI exhibited a normal distribution or not was determined using the Kolmogorov Smirnov test. Since the patients did not display a normal distribution, Kruskal-Wallis test was employed for group comparisons.

\section{RESULTS}

A total of 426 OSAS patients with a mean age of 51.5 \pm 10.2 years (23-82) were included in this study. Of these patients, $306(71.8 \%)$ were male. It was established that $282(66.2 \%)$ of all patients were obese (BMI $>30 \mathrm{~kg} / \mathrm{m}^{2}$ ). The mean BMl of the patients was $33.0 \pm$ $6.3(20.7-58.9) \mathrm{kg} / \mathrm{m}^{2}$. The mean BSA of the patients, on the other hand, was $2.06 \pm 0.20 \mathrm{~m}^{2}(1.57-2.94)$ and $2.11 \pm 0.21 \mathrm{~m}^{2}(1.61-3.03)$ respectively based on the Mosteller and Boyd formulas. The general characteristics of the patients are demonstrated in Table 1.

In addition to $\mathrm{BMI}$ and $\mathrm{BSA}$, mean values of oxygen saturation, oxygen desaturation, $\mathrm{AHI}$, sleep efficiency, ODI, and minimum oxygen saturation are demonstrated in Table 1. Patients were grouped into the following 
three categories based on their $\mathrm{AHI} ; 108$ patients (25.4\%) with mild OSAS (AHI: 5-15), 97 patients (22.8\%) with moderate OSAS (AHI: 15-30) and 221 patients $(51.9 \%)$ with severe OSAS $(\mathrm{AHI}>30)$.

\begin{tabular}{|c|c|}
\hline & Mean \pm SD \\
\hline Age & $51.5 \pm 10.2$ \\
\hline \multicolumn{2}{|l|}{ BMI } \\
\hline \multicolumn{2}{|c|}{ Normal weight $(\mathrm{n}=24, \mathrm{BMI}<25)$} \\
\hline Obes $(\mathrm{n}=282, \mathrm{BMI}>30)$ & $33.0 \pm 6.3$ \\
\hline \multicolumn{2}{|c|}{ Morbidly obes $(n=55, \mathrm{BMI}>40)$} \\
\hline \multicolumn{2}{|l|}{ BSA } \\
\hline Monsteller & $2.06 \pm 0.20$ \\
\hline Boyd & $2.11 \pm 0.21$ \\
\hline \multicolumn{2}{|l|}{$\mathrm{AHI}$} \\
\hline \multicolumn{2}{|l|}{ Mild $=25.4 \%$} \\
\hline Moderate $=22.8 \%$ & $38.0 \pm 27.8$ \\
\hline \multicolumn{2}{|l|}{ Severe $=51.9 \%$} \\
\hline Oxygen desaturation & $13.5 \pm 23.5$ \\
\hline Sleep efficiency & $82.4 \pm 10.4$ \\
\hline \multicolumn{2}{|l|}{ Wakefullness oxygen saturation } \\
\hline ODI & $35.4 \pm 29.8$ \\
\hline Mean oxygen saturation & $92.5 \pm 4.4$ \\
\hline Minimum oxygen saturation & $76.9 \pm 13.1$ \\
\hline
\end{tabular}

Table 2 demonstrated the polisomnographic analysis of the cases grouped according to the severity of the disease. BMI, AHI, oxygen desaturation, ODI, awakeness oxygen saturation, mean oxygen saturation, and minimum oxygen saturation, parameters were found statistically different between the groups.

Both BMI and BSA (as calculated using the said formulas) correlated positively with $\mathrm{AHI}$, oxygen desaturation and ODI and negatively with mean oxygen saturation, wakefulness oxygen saturation, and minimum oxygen saturation (Table 3).

As to the BMI and BSA differences between males and females grouped according to the severity of disease, there were no significant BMI and BSA (as calculated by both formulas) differences between the genders in patients with a mild disease. In patients with a moderate-to-severe disease, on the other hand, BMI was significantly higher among females and BSA (as calculated by the Mosteller formula) was significantly higher among males.

We showed all cases according to OSAS severity in Table 4. In all groups BMI was higher in females than males. BSA calculated by Monsteller formula in all groups was higher in males than females. In mild cases BSA calculated by Boyd were higher in males than females (Table 4).

Table 5 demonstrates the sensitivity and specificity of $\mathrm{BMI}$ and BSA for the prediction of the disease in both genders with severe OSAS. It is clear from the table that BSA and BMI display similar sensitivity and specificity values for the prediction of severe OSAS.

Table 2. Polysomnographic analysis of the cases according to severity of the disease

\begin{tabular}{|c|c|c|c|c|}
\hline & $\begin{array}{c}\text { Mild } \\
(n=108) \\
\text { Mean } \pm \text { SD }\end{array}$ & $\begin{array}{c}\text { Moderate } \\
(n=97) \\
\text { Mean } \pm \text { SD }\end{array}$ & $\begin{array}{c}\text { Severe } \\
(n=221) \\
\text { Mean } \pm \text { SD }\end{array}$ & $\mathbf{p}$ \\
\hline Age (years) & $51.0 \pm 8.9$ & $50.8 \pm 10.3$ & $52.1 \pm 10.7$ & 0.393 \\
\hline BMI $\left(\mathrm{kg} / \mathrm{m}^{2}\right)$ & $30.2 \pm 4.7$ & $32.1 \pm 6.1$ & $34.8 \pm 6.4$ & $<0.0001$ \\
\hline $\mathrm{AHI}$ & $9.8 \pm 2.9$ & $22.0 \pm 3.9$ & $58.8 \pm 23.3$ & $<0.0001$ \\
\hline Oxygen desaturation & $0.7 \pm 2.0$ & $5.7 \pm 14.4$ & $23.2 \pm 27.9$ & $<0.0001$ \\
\hline Sleep efficiency & $83.3 \pm 10.0$ & $83.2 \pm 9.6$ & $81.66 \pm 10.91$ & 0.438 \\
\hline ODI & $7.9 \pm 4.3$ & $19.0 \pm 6.6$ & $56.2 \pm 27.7$ & $<0.0001$ \\
\hline Wakefullness oxygen saturation & $95.5 \pm 1.1$ & $94.5 \pm 2.1$ & $93.4 \pm 3.5$ & $<0.0001$ \\
\hline Mean oxygen saturation & $94.9 \pm 1.5$ & $93.5 \pm 2.8$ & $90.8 \pm 5.3$ & $<0.0001$ \\
\hline Minimum oxygen saturation & $85.9 \pm 5.1$ & $81.6 \pm 7.0$ & $70.4 \pm 14.3$ & $<0.0001$ \\
\hline
\end{tabular}


Table 3. Correlation between polysomnographic analysis with BSA and BMI

\begin{tabular}{|c|c|c|c|c|c|c|}
\hline & \multicolumn{2}{|c|}{ BMI } & \multicolumn{4}{|c|}{ BSA } \\
\hline & \multirow[b]{2}{*}{$r$} & \multirow[b]{2}{*}{$\mathbf{p}$} & \multicolumn{2}{|c|}{ Boyd } & \multicolumn{2}{|c|}{ Monsteller } \\
\hline & & & $\mathbf{r}$ & p & $r$ & p \\
\hline $\mathrm{AHI}$ & 0.415 & 0.000 & 0.360 & 0.000 & 0.332 & 0.000 \\
\hline Desaturation & 0.519 & 0.000 & 0.375 & 0.000 & 0.325 & 0.000 \\
\hline Sleep efficiency & -0.120 & 0.013 & -0.054 & 0.263 & -0.045 & 0.356 \\
\hline ODI & 0.519 & 0.000 & 0.411 & 0.000 & 0.375 & 0.000 \\
\hline Wakefullness oxygen saturation & -0.372 & 0.000 & -0.314 & 0.000 & -0.281 & 0.000 \\
\hline Mean oxygen saturation & -0.476 & 0.000 & -0.378 & 0.000 & -0.338 & 0.000 \\
\hline Minimum oxygen saturation & -0.512 & 0.000 & -0.323 & 0.000 & -0.272 & 0.000 \\
\hline
\end{tabular}

Table 4. The comparisons of BMI and BSA between male and female patients according to OSAS severity

\begin{tabular}{|c|c|c|c|c|c|c|c|c|c|}
\hline \multirow[b]{3}{*}{ Measures } & \multicolumn{8}{|c|}{ OSAS severity } & \multirow[b]{3}{*}{$\mathbf{p}$} \\
\hline & \multicolumn{2}{|c|}{ Mild } & \multirow[b]{2}{*}{$\mathbf{p}$} & \multicolumn{2}{|c|}{ Moderate } & \multirow[b]{2}{*}{ p } & \multicolumn{2}{|c|}{ Severe } & \\
\hline & Male & Female & & Male & Female & & Male & Female & \\
\hline $\mathrm{BMI}\left(\mathrm{kg} / \mathrm{m}^{2}\right)$ & 28.7 & 31.6 & 0.000 & 30.8 & 35.1 & 0.003 & 33.1 & 37.5 & 0.000 \\
\hline Mosteller $\left(\mathrm{m}^{2}\right)$ & 2.01 & 1.94 & 0.002 & 2.06 & 1.95 & 0.031 & 2.11 & 2.04 & 0.007 \\
\hline Boyd $\left(\mathrm{m}^{2}\right)$ & 2.04 & 2.00 & 0.013 & 2.11 & 2.02 & 0.123 & 2.15 & 2.09 & 0.079 \\
\hline
\end{tabular}

Table 5. Cut-off values of the anthropometric parameters for predicting of severe OSAS

\begin{tabular}{|c|c|c|c|c|c|c|}
\hline & & & \multicolumn{4}{|c|}{ BSA } \\
\hline & \multicolumn{2}{|c|}{ BMI } & \multicolumn{2}{|c|}{ Monsteller } & \multicolumn{2}{|c|}{ Boyd } \\
\hline & Female & Male & Female & Male & Female & Male \\
\hline Area under the ROC curve & 0.692 & 0.698 & 0.679 & 0.628 & 0.684 & 0.641 \\
\hline Cut-off value & $>38.6$ & $>30.8$ & $>1.96$ & $>2.07$ & $>2.04$ & $>2.12$ \\
\hline Sensitivity $(95 \% \mathrm{Cl})$ & 45.90 & 71.87 & 70.49 & 60.62 & 63.93 & 61.25 \\
\hline Specificity $(95 \% \mathrm{Cl})$ & 86.44 & 60.96 & 59.32 & 58.90 & 67.80 & 60.27 \\
\hline
\end{tabular}

\section{DISCUSSION}

The main purpose of the present study was to explore the possibility of using BSA as a new anthropometric measurement in evaluation of OSAS cases. Considering the finding in the present study that the severity of OSAS was increased with BMI and BSA, it might be suggested that such a possibility exists. In addition, the significant correlation BSA displayed not only with the indirect determinants of the severity (oxygen desaturation, ODI, wakefulness oxygen saturation, mean oxy- gen saturation and minimum oxygen saturation) but also with AHI, a direct determinant of the severity, points out to the possibility that BSA can be instrumental in evaluating patients with a clinical suspicion of OSAS before performing a proper PSG. On the other hand, although BMI and BSA display a significant correlation with several polysomnographic parameters, they have low sensitivity and specificity for the prediction of OSAS especially in severe cases. Therefore, PSG holds its place as a valuable tool in the diagnosis of OSAS. To the best of our knowledge, this is the first 
study in the literature to examine the potential association between BSA and the severity of OSAS.

The most obvious risk factors for OSAS are male sex and obesity $(1,5,10,22)$. Obesity is a major risk factor that is well established by several studies (23-25). Especially central obesity has been shown to increase tendency to OSAS. Studies report that $60-75 \%$ of all patients with OSAS suffer from obesity $(23,26,27)$. In agreement with the literature data, $65.3 \%$ of the patients were found to be obese in the present study.

The most commonly used measurements in the diagnosis of obesity are BMI, waist circumference (WC) and hip circumference (HC). Bouloukaki et al. stated that BMI was a better indicator than others in OSAS predictability (28). In the present study, NC as well as BMI was found to be significant for OSAS predictabilaty (29). Patients with OSAS exhibit significantly higher values of BMI, waist-to-hip ratio and neck circumference compared to control subjects $(8,9)$. Sari et al. reported in patients with OSAS that BMI and $\mathrm{NC}$ correlated significantly with $\mathrm{AHI}$, which was a parameter employed to determine the severity of disease in both genders. They also reported that in all patients NC correlated with AHI better than BMI (30). Danket et al. and Sreedharan et al. also pointed out to a significant correlation between BMI and the severity of OSAS $(31,32)$. In their study, Evlice et al. reported similar mean BMI values in patients with OSAS and healthy control subjects (33). In the present study, the severity of disease was increased with BMI. Furthermore, as a new finding, a concurrent increase was also observed in BSA and the severity of disease. Absence of a healthy control group might be considered a limitation of the present study.

There was no correlation between BMI and ODI in the study conducted by of Yakar et al. (34). In the present study, on the other hand, not only BMI but also BSA correlated significantly with ODI. Ersnt et al. observed that $\mathrm{AHI}$ and $\mathrm{ODI}$ increased progressively with obesity grade and the said increase was associated with BMI only in men (35). In the present study, there was a significiant association between BMI and BSA (as calculated using the Monsteller formula) and the severity of OSAS.

In agreement with the results of the present study, Chung et al. reported a strong correlation between $\mathrm{ODI}$ and $\mathrm{AHI}(36)$.

Jeong et al. reported in male subjects that BMI, WC, and overall body fat were significantly associated with the severity of OSAS (8). In the present study, a significant association was found between $\mathrm{BMI}$ and the severity of disease in both genders.

\section{CONCLUSION}

Although BMI and BSA display low sensitivity and specificity for the prediction of OSAS especially in severe cases, they have a significant correlation with several polysomnographic parameters used to establish the diagnosis and the severity of OSAS. Therefore, BSA as well as BMI might useful in evaluating patients with a clinical suspicion of OSAS before performing a proper PSG. We are of the opinion that BSA, as an anthropometric measurement, can be employed in case of a clinical suspicion of OSAS for establishment of correct and selective indications for PSG. The

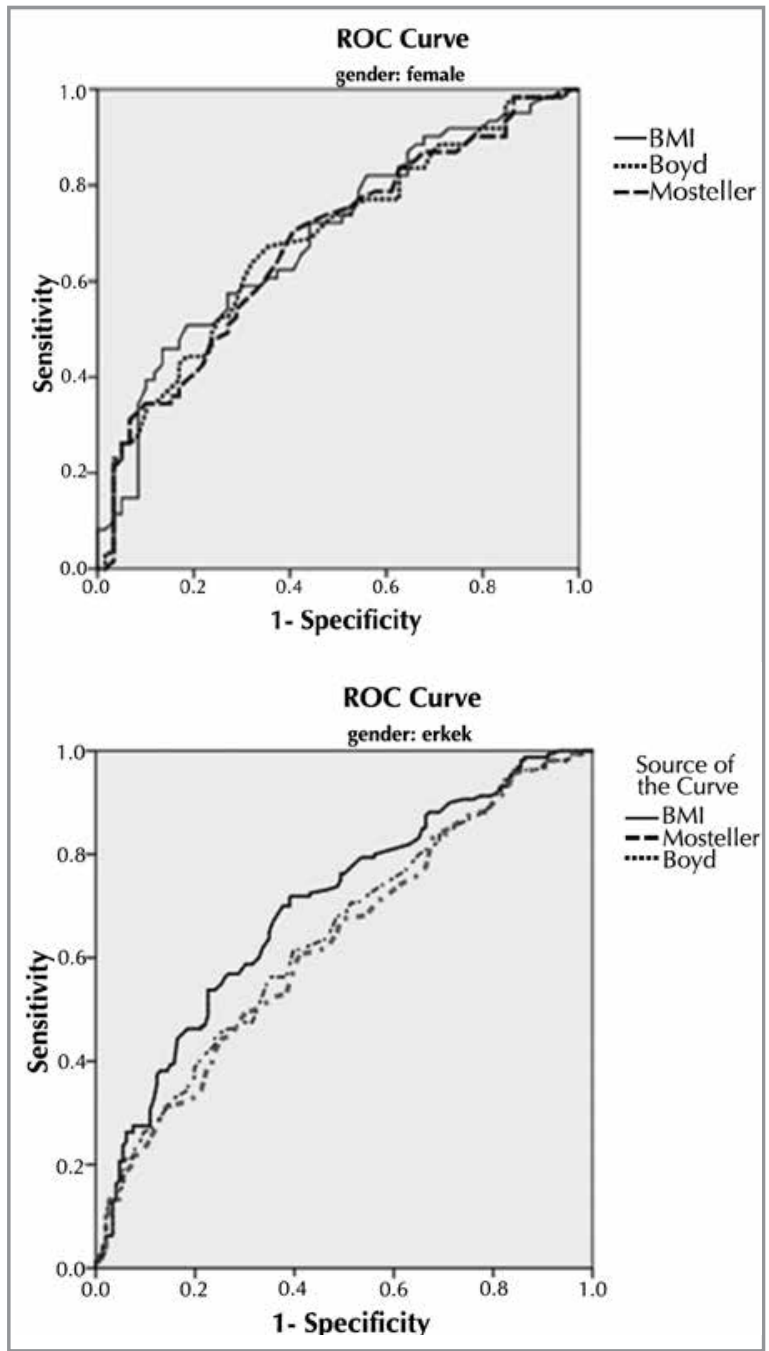

Figure 1. ROC curves in males and females for BMI and BSA. BMI: Body mass index, BSA: Body surface area. 
absence of a healthy control group was considered a limitation of the present study.

Considering the significant correlation between BSA and the polysomnographic parameters, clinicians can rely on BSA as well as BMI in preliminary evaluation of patients with a clinical suspicion of OSAS.

\section{REFERENCES}

1. Gaudette E, Kimoff RJ. Pathophysiology of OSA. Eur Respir Mon 2010;50:31-50.

2. Kuna S, Remmers JE. Anatomy and physiology of upper airway obstruction. In: Kryger MH, Roth T, Dement WC (eds). Principles and practice of Sleep Medicine. $3^{\text {rd }}$ ed. Philadelphia: W.B. Saunders Company 2008:840-58.

3. Schwab RJ, Remmers JE, Kuna ST. Chapter 101 - anatomy and physiology of upper airway obstruction. In: Kryger MH, Roth T, Dement WC (eds). Principles and Practice of Sleep Medicine, $5^{\text {th }}$ ed. Missouri: Elsevier Saunders, 2011:1153-71.

4. European Respiratory Society Monograph, Vol. 502010. Epidemiology of OSA. Lindberg E. Eur Respir Mon 2010; 50:51-68.

5. Young T, Skatrud I, Peppard PE. Risk factors for obstructive sleep apnea in adults. JAMA 2004;291:2013-16.

6. Vgontzas AN, Tan TL, Bixler EO, Martin LF, Shubert D, Kales A. Sleep apnea and sleep disruption in obese patients. Arch Intern Med 1994;154:1705-11.

7. Redline S, Tishler PV, Tosteson TD, Williamson J, Kump K, Browner I, et al. The familial aggregation of obstructive sleep apnea. Am J Respir Crit Care Med 1995;151:682-7.

8. Jeong JI, Gu S, Cho J, Hong SD, Kim SJ, Dhong HJ, et al. Impact of gender and sleep position on relationships between anthropometric parameters and obstructive sleep apnea syndrome. Sleep Breath 2017;21:535-41.

9. Mosharraf-Hossain AK, Ahmed K, Islam MT, Chakrabortty R. A community study of obstructive sleep apnea hypopnea syndrome (OSAHS) in middle-aged bangladeshi population. Bangladesh Med Res Counc Bull 2015;41:138.

10. Ayık SO, Akhan G, Peker S. Frequency of Obesity and concomittant diseases in patients with obstructive sleep apnea syndrome (OSAS). Tur Toraks Der 2011;12:10510.

11. Body surface area for adjustment of drugdose. Drug Ther Bull 2010:48:33-6.

12. Kouno T, Katsumata N, Mukai $M$, Ando M, Watanabe $T$. Standardization of the body surface area (BSA) Formula to calculate the dose of anticancer agents in Japan. Jpn J Clin Oncol 2003;33:309-13.
13. Redlarski G, Palkowski A, Krawczuk M. Body surface area formulae: an alarming ambiguity. 2016; Scientific Reports 6, Article number: 27966.

14. Fukazawa K, Yamada Y, Nishida S, Hibi T, Arheart KL, Pretto EA Jr. Determination of the safe range of graft size mismatch using body surface area index in deceased liver transplantation. Transpl Int 2013;26:724-33.

15. DuBois D, DuBois EF. A Formula to estimate the approximate surface area if height and weight be known. Arch Intern Med 1916;17:863-71.

16. Miller AA, Rosner GL, Egorin MJ, Hollis D, Lichtman SM, Ratain MJ. For the cancer and leukemia group $B$. Prospective evaluation of body surface area as a determinant of paclitaxel pharmacokinetics and pharmacodynamics in women with solid tumors: cancer and leukemia group B study 9763. Clin Cancer Res 2004;10:8325-31.

17. Mosteller RD. Simplified calculation of body-surface area. N Engl J Med 1987;317:1098.

18. Boyd E. Institute of child welfare, monograph series 10. minneapolis: University of Minnesota Press, 1935. The growth of the surface area of the human body.

19. Mathijssen RH, de Jong FA, Loos WJ, van der Bol JM, Verweij J, Sparreboom A. Flat-fixed dosing versus body surface area based dosing of anticancer drugs in adults: does it make a difference? Oncologist 2007; 12:913-23.

20. American Academy of Sleep Medicine. International classification of sleep disorders. Diagnostic and coding manual (ICSD-2). $2^{\text {nd }}$ ed. American Academy of Sleep Medicine: Westchester, IL, 2005.

21. World Health Organization (2000) Obesity: preventing and managing the global epidemic. Report of a WHO consultation. WHO Tech Rep Ser 894:1-253.

22. Köktürk O, Ulukavak Çiftçi T. Obstrüktif uyku apne sendromu. Genel önlemler ve medikal tedavi. Tuberk Toraks 2002;50:119-24.

23. Smith P, Gold A, Meyers D, Haponik E. Weightloss in mildly to moderately obese patients with obstructive sleep apnea. Annals of Internal Medicine 1985;103:850-5.

24. Suratt P, Metier R, Findley L, Pohl S, Wilhoit S. Changes in breathing and the pharynx after weight loss in obstructive sleep apnea. Chest 1987;92:631-7.

25. Wittels E, Thompson S. Obstructive sleep apnea and obesity. Otolaryngologic Clinics of North America 1990;23;751-60

26. Schwab RJ, Goldberg AN, Pack AL. Sleep apnea syndromes. Fishman's pulmonary diseases and disorders. Ed: Fishman AP. New York: McGraw Hill Book Company 1998; 1617-37.

27. Vgontzas AN, Papanicolaou DA, Bixler EO, Hopper K, Lotsikas A, Lin HM, et al. Sleep apnea and daytime sleepiness and fatigue; relation to visceral obesity, insülin resistance, and hypercytokinemia. The I Clin Endocrinol Metab 2000;85:1151-8. 
28. Bouloukaki I, Kapsimalis F, Mermigkis C, Kryger $M$, Tzanakis N, Panagou P, et al. Prediction of obstructive sleep apnea syndrome in a large greek population. Sleep Breath 2011;15:657-64.

29. Sahin M, Bilgen C, Tasbakan MS, Midilli R, Basog/u OK. A clinical prediction formula for apnea-hypopnea index. Int J Otolaryngol 2014;2014:438376.

30. Sarı H, Acar G, Yakut H, Tekin M, Özdamar OI. Corelation of apnea hypoapnea index concerned with body mass index and neck circumference measurements in patients with obstructive sleep apnea syndrome. Turk Arch Otorhinolaryngol 2011;49:67-73.

31. Dancey DR, Hanly PJ, Soong C, Lee B, Shepard J Jr, Hoffstein V. Gender differences in sleep apnea: the role of neck circumference. Chest 2003;123:1544-50.

32. Sreedharan SE, Agrawal P, Rajith RS, Nair S, Sarma SP, Radhakrishnan A. Clinical and polysomnographic predictors of severe obstructive slee papnea in the south indian population. Ann Indian Acad Neurol 2016;19:21620 .
33. Evlice A, Ugurel B, Baklan B, Oztura I. Neuropathy and dysautonomia in patients with obstructive sleep apnea syndrome. Arch Neuropsychiatr 2015;52:24-8.

34. Yakar F, Yakar A, Sezer M, Erelel M. Role of daytime polysomnography in the diagnosis of sleep apnea syndrome. Tuberk Toraks 2015;63:78-85.

35. Ernst G, Bosio M, Salvado A, Dibur E, Nigro C, Borsini E. Difference between apnea-hypopneaindex (AHI) and oxygen desaturation index (ODI): proportional increase associated with degree of obesity. Sleep Breath 2016;20:1175-83.

36. Chung F, Liao P, Elsaid H, Islam S, Shapiro CM, Sun Y. Oxygen desaturation index from nocturnal oximetry: a sensitive and specific tool to detect sleep disordered breathing in surgical patients. Anesth Analg 2012;114:9931000. 